\title{
The Realization of "Two Hundred Years" and Try to Cultivate Five Kinds of Literacy of College Counselors
}

\author{
Shucheng $\mathrm{Shi}^{1, \mathrm{a}}$ \\ Student Department, Jilin Agricultural University, Changchun, China, 130118 \\ ${ }^{\mathrm{a}}$ emai 1
}

Keywords: Achieve "Two Hundred Years" Goal, Cultivate College Counselors Literacy

\begin{abstract}
Eighteen presented the party's "two hundred years" the ambitious targets, planning to achieve national rejuvenation of the grand blueprint for the people across the country pointed out the direction of struggle, with real passion chasing the dream. The great dream come true, inseparable from the people's support, and personnel training is an important duty of College Counselors. Research based on the country's future development and historical background, focus to achieve "two hundred years" goal, training century talents, cultivating college counselor made five qualities, namely: political literacy, mission accomplishment, age literacy, humanities and law accomplishment.
\end{abstract}

\section{Introduction}

After the party's 18, our party and state undertakings in various fields gradually opened up new journey, political, economic, military, technological, cultural and other constantly undergoing major changes, new ideas, new ideas, new ideas constantly innovation, impact and Inquiries people's minds. In the economic sphere, the economic development has entered a new normal, continuous reform crucial depth and innovation to create wind and water; in the field of culture, Chinese traditional culture and revitalize, into the heart, to the world, has been a greater carry forward; in science and technology major scientific and technological achievements continue to emerge, attracted worldwide attention; in the realm of ideas, "two hundred years" targeted people in the struggle for the direction, "China dream" has become the common denominator unity universal ideology, socialist core values to get more and more person's identity and practice; in the field of ethics, moral people began to return, continue to carry forward the good and the beautiful, as society gradually goodness, morality Woon, positive energy to get more and more recognition, Chong Yang and dissemination; in areas of social life, people are more concerned about health, concern for the environment, concerned about the world, public-spirited, to maintain the country's image, more and more people talk about the dedication to play, talk about the moral character and so on, these new changes, new fashion, new scenes, vividly to the national people's march " two hundred years "goal in the process, and to achieve lofty goals need Relay generations of struggle, educating people to shoulder responsibility as a college counselor, to focus on cultivating" five kinds of literacy "in order to better contribute to the cause of education.

\section{The Realization of "Two Hundred Years" and Cultivate College Counselors Political Literacy}

Talent is the country's prosperity and social progress of the determinants in the 21st century is the most precious talent. The party's 18 report planning blueprint for future development of our country, proposed the "two one hundred," the vision, and ultimately achieve this goal without talent, and with the development and growth of more, more people need support, therefore, must be based on college counselors to achieve "two hundred years" goal, cultivate talents century, it is necessary to foster a comprehensive political literacy, and enhance awareness of the global, national and political awareness. First, cultivate a high degree of political responsibility. College is the cradle of training, whether training to adapt to national development needs, promoting social progress, create social 
value of useful talents, the key is to determine whether the achievement of the ambitious goals, the relationship is the key to the great rejuvenation of the Chinese dream can be achieved. As a college teachers training, responsibility and arduous tasks glorious mission. Facing the new situation, new tasks and new requirements, colleges and universities have been given a higher counselor heavier responsibility of educating people, students' ideological training excellent or not, politics is qualified or not, quality good or not, moral or not, decide the future of the country's future, the future of society and the nation. College Counselors should realize national rejuvenation stand on the highest point of political awareness of their work and fulfill their duties, the only way to the training of personnel as a mission to play, in order to continuously cultivate talents. The second is keen to cultivate political support discrimination. College Counselors is the party's theory, policy advocates and practitioners, is our national policies and the implementation of educational philosophy to students, become a bridge and link student actions, therefore, whether a firm political stance college counselors, thinking is correct or not, directly affect the students thinking, influence the direction and quality of our personnel training. With the deepening of China's economic development and to accelerate the integration process in the world, our society blend of ideas, interaction, confrontation, cultural pluralism, diversity, information cohabitation, ideological struggle of the more subtle and complex, especially domestic and foreign hostile forces to infiltrate our thinking, differentiation, evolution intensifies, severe confusion audiovisual students to interfere with the student's thinking. How to make students in the complicated environment, always right and wrong, Jizhuoyangqing, always maintain the correct ideological course, it is the political responsibility of the college counselors. Therefore, college counselors should have the political power of discrimination, it is possible to distinguish the authenticity, truth known, set the record straight, take the initiative in the ideological field, hold the position, at any time give students the right to lead, to ensure that students establish a correct outlook on life and values.

\section{The Realization of "Two Hundred Years" and Cultivate College Counselors Mission Accomplishment}

Achieve "two hundred years" goal, firmly establish and internalization of the Socialist core values at the heart of compliance. Socialist core values and moral standards provide for people, values and code of conduct, foster socialist core values and practice, leading to the need to mainstream the positive direction, need role models to lead to point, you need to deep water into a river, which the during both practice college counselor who is also a leader, but also demonstrator. Therefore, we should actively strengthen comprehensive college counselors mission accomplishment. To establish a new work standards. Socialist core values are formed and the correction everyone the world, life and values establish a new scale, in terms of just the individual level, patriotic, dedicated, honest, friendly, not only the conduct of each college counselors, it is 21 College counselors century German self-cultivation, demeanor code of conduct, is engaged in the supreme counselor requested occupations. Universities Students counselors are the soul of the shapers are exemplary and grow guides for college students' behavior must be relentless in the pursuit of personal values level, efforts to slim, hard practice, reaching perfection, so that their thinking and actions always reflect the core values of the era of light to illuminate the students' growth on the road, lit lighthouse students thinking, so that students voluntarily under appeal in the era before the trip. College Counselors only in accordance with the core values of their own requirements, in order to better fulfill its mission responsibility, constantly enrich the connotation of socialist core values, improving quality standards work better realize the value of life. Second, we must enhance the appeal of the times. Charisma means in order to make others agree or support their attitudes, opinions or behavior, persuasion, demonstration and other methods to convince others to make the ability to agree with [1]. At present, the rapid development of society, all kinds of thoughts are surging, raging various information to students in a skeptical age, a "scraper", and it's a lack of "self", in this environment, requiring counseling members can adhere to the socialist core values as the yardstick, always stand on the position of the country, and actively promote the party's ideology and ideas, to promote the national policy guidelines, and constantly deliver the right sound to the 
students, and the ability to inspire students to be convinced, obey, respect, respect, infection educate students listen to the party, with the party, leading the student keep up the trend into the mainstream of the times, to become building socialism with Chinese characteristics and realize national rejuvenation contributors. Third, we must cultivate consciously practice the force. Xi Jinping, general secretary repeatedly stressed that "empty talk, hard work and prosperous," and in the 12th National People's Congress first meeting that " 'Gong Chong Wei Chi, Yeh-kwong, but ground', China is still in and long-term primary stage of socialism, China realize the dream, all the people to create a better life, long way to go, we need everyone to continue to pay the hard work and hard work [2]. "great dream has been clearly revealed, but to reach the ideal of the other side, you need to turn the numerous Xianfeng across numerous ravines, before the call of the times, everyone rowing in rapids, college counselors should enhance the consciousness, the master consciousness, awareness actions, and actively participate work, consciously practice the socialist core values, will be the pursuit of dreams turned into power training, to enable students to see the sense of urgency to the efforts for the dream to see the hard work to realize their dreams, stream water momentum to "do not spontaneous," Consciousness, cultivate more excellent quality, high quality, professional fine high-level talent, it is the highest interpretation of career counselors.

\section{The Realization of "Two Hundred Years" and Cultivate Literacy Era College Counselors}

Xi Jinping, general secretary, said: "Now we are closer to the goal of the great rejuvenation of the Chinese nation than at any time in history." Face a new era, the era of literacy to focus on cultivating college counselors, and actively join the era, the era of active contribution. First, foster lofty ideals and beliefs. Lofty ideals and beliefs is the cause continues to target power success. Actively organize ideals, beliefs, outstanding cultural heritage education, vocational counselors identity and self-discipline education, vocational counselors firm over and improve counselor thought highly, lofty ideas inspire great power. Second is to cultivate the spirit of reform and innovation. Before the era of development and progress needs new talent Relay line, talented people need to lead innovation. Students learn in addition to in-depth expertise in the spiritual realm, behavior, ideology and other aspects also need to continue to lead the education. Counselors should abandon the traditional teaching methods of thinking and backward, in the era of "public entrepreneurship and innovation," driven, constantly updated ideas, learn new knowledge and technology, innovative ways and means forefront of the times, adapt to future needs nurture new talent. Third is to cultivate the spirit of courage to play. Counselors should stand state and the nation's future, nurturing the bigger picture, the vision, mind, establish a "country and the world," the responsibility, that the sense of responsibility to nurture talent prosperity of the country treated duties, national rejuvenation contribution that youth play wit awareness work hard and inspire selfless work of the spirit, into the spiritual power of the times, in order to improve the quality of education. Fourth, cultivate the spirit of dedication. Dedication is the special requirements of professional colleges counselor positions. "Higher standards of professional competence Counselors" in the provisions of the Code counselor occupation, counselor to "love the party of education, occupation and establish lofty ideals, devotion to the cause of education, leading students' ideological and student development service mission." Therefore, counselors should educate people as their career aspirations to love righteousness and selfless dedication, the work of job counselors treat, treat nurtured by the next session of the students, hard work education.

\section{The Realization of "Two Hundred Years" and Cultivate College Counselors Humanities}

Humanities is a country, a nation important foundation of self-reliance, the loss of humanities, they also lose the soul of a nation, let alone development and progress. Outstanding students, is inseparable from the humanities conservation, which requires the counselor must have strong humanistic qualities. First, rich cultural knowledge reserves. Counselors knowledge humanistic spirit culture, background and content of human knowledge can not be separated, so counselors should actively dabbled in literature, history, philosophy, ethics, art, aesthetics and other aspects, by 
listening to presentations, reading activities and elegant art appreciation actively enrich the connotation of knowledge, broaden horizons of thinking, and constantly improve artistic taste, aesthetic ability, philosophical thinking and so on. Second is to strengthen ethics style culture. In 2014, the US third-party research firm lid Poor's live nationwide 30,000 college graduates of all ages Graduation satisfaction years later conducted a survey and found that, throughout the different ages of University graduates, regardless of their work long life, if there is a close attention to them, to guide them to grow and develop, to stimulate their interest in learning, encourage them to pursue their dreams "soul mentor" [3] depend on their passion for work during university. As can be seen, a good teacher, especially the teacher excellent instructor for students to grow in importance, therefore, counselors should take the initiative to tap the resources from the humanistic knowledge, the humanistic spirit extracted from the historical accumulation, depicting cultivate their human temperament, inherit and carry forward the fine virtue sages in the counselor positions, continue to strengthen learning and training, keep practicing moral character, cultivate perfect character, created good morality style, and set an example for the students to set up a model to noble personality and accomplishment, guide students to pursue good and the beautiful. Third, the rich social experience. Social practice is counselor self-improvement, self-growth, enhance the humane quality, effective way of shaping the humanistic spirit. Current college counselors mostly young "80," the understanding of social and cognitive sentiments clearly insufficient, counselors should actively organize at the grassroots level testing exercise, to the grassroots investigation and study, to participate in social productive labor and social services etc., help counselors understand the community in social practice, understanding of our country, in dealing with their own field of work, will be handy, targeted. Fourth, to actively create a cultural atmosphere. Strengthen the construction of campus culture is an effective way to enhance the humanistic spirit of college counselors, counselors should actively organize staff to participate in painting and calligraphy exhibition, essay contests, debating contest, art show and other colorful cultural activities, on the one hand the rich leisure life faculty on the other hand also trained staff taste, to create a good cultural atmosphere.

\section{Realization of "Two Hundred Years" and Cultivate Legal Literacy of College Counselors}

The rule of law, promote the rule of law is the consistent stand of our party, the party's congress, eighteen reports to carry forward the socialist rule of law for a special emphasis. Thus, the rule of law foster literacy, is the common choice of all citizens, and more important responsibilities is educating people mandate college counselors. First, we must respect the authority of law. Eighth session of the Fourth Plenary Session December 4 each year as a national Constitution Day, it establishes clear lofty constitutional status awaken a strong desire of the whole society to carry forward the spirit of the rule of law, respect of legal authority for carrying out the rule of law to provide education in universities a good opportunity to carry forward the spirit of the Constitution should become counselors pioneer, therefore, counselors must first establish a positive sense of the rule of law, the fear of the law, respected the law, always work to maintain the sanctity of the Constitution and the law. The second is to learn legal knowledge. To foster the rule of law under the premise of knowing understanding, law-abiding law enforcement in order to safeguard the dignity of law, promote the rule of law. "Higher standards of professional competence counselor" clear, counselor to grasp the "People's Republic of China Education Law", "People's Republic of China Higher Education Law" and other laws and regulations eleven knowledge [4], which is the counselor work better basis to perform their duties, but also the new requirements of the times. At the same time, in the new situation, we face many legal problems arising labor disputes students' employment, employment discrimination, counselors should also strengthen the "Labor Law", "Contract Law" and other concerns the vital interests of the student's knowledge of the law learning, and actively adapt to the students' growth and development needs. On this basis, gradually cultivate the rule of law thinking. Third, in-depth practice to consolidate. Students work to carry out the process, to establish the rule of law thinking in the matter of the students to join the party, appraised, awards, etc. adhere to fair, just play by the rules, according to the system, to maintain the dignity of the system, in order to comply with law abiding student demonstration. In the process of educating 
people to be thinking always keep in mind the rule of law, for the behavior of students, large constitutional law, to the rules and regulations, small order to regulate, discipline rules, repeatedly stressed that the sustained delivery, time to show his line to have been of people, and establish a firm rule of law thinking.

\section{References}

[1] Yang Song, Ma Zhuang, Zhou Gang. Counselors Professional Ability in Universities [J]. Journal of Changzhou Institute of Information Technology, 2012.4.

[2] Xi Jinping talk of governance [M]. Beijing: Foreign Languages Press, 2014.

[3] Wang Luyan. Students first professional title position [J]. MyCOS research, 2015.10.

[4] Universities counselor professional ability standards (provisional) [Z]. 2014. 